\title{
Factors favoring houseplant container infestation with Aedes aegypti larvae in Marília, São Paulo, Brazil
}

\author{
M. L. G. Macoris, ${ }^{1}$ C. A. B. Mazine, ${ }^{2}$ M. T. M. Andrighetti, ${ }^{2}$ \\ S. Yasumaro, ${ }^{2}$ M. E. Silva, ${ }^{2}$ M. J. Nelson, ${ }^{2}$ and P. J. Winch $^{3}$
}

ABSTRACT Since reinvasion of São Paulo State by the Aedes aegypti (L.) mosquito in 1985, flower pots and vases have been important larval habitats despite educational messages focusing on their control. The objectives of this study were to characterize flower pots and vases as larval habitats with respect to the quantities present and infested, the types of plants involved, and the specific locations of the mosquito larvae; to explore local names for houseplants; and to examine factors affecting acceptance of control measures. The results showed an average of more than four potential plant-related larval habitats per premises, of which only $0.4 \%$ were occupied by the vector. Plant-related containers represented 31\% of all the containers with Aedes aegypti larvae. Although a sample of 126 respondents was able to list 105 different houseplant names, $49 \%$ of the positive plants were of two types: ferns and the ornamental plant Dieffenbachia avoena. The public's apparent unwillingness to accept recommended anti-aegypti control measures involving houseplants seems related to the relative rarity of aegypti larvae in the very common houseplant containers, the control program's poor credibility as a source of information about plants, and a perception that the recommended control measures are harmful to plants. An intervention currently being planned for dengue control will use educational material that refers specifically to those plants whose containers are most commonly found to harbor aegypti larvae; it will also utilize information sources such as botanists with greater credibility regarding plants; and it will set out alternative plant care recommendations that are more likely to appeal as beneficial to the plants and that will stand a better chance of being accepted.

One of the characteristics that distinguishes Aedes aegypti (L.) from other mosquito species is the ability of its lar-

\footnotetext{
Directorate for Endemic Disease Control (Superintendência de Controle de Endemias-SUCEN), Marília, São Paulo, Brazil.

2 Pan American Health Organization (Organização Panamericana da Saúde), Brasília DF, Brazil.

3 Center for International Community-based Health Research, Department of International Health, Johns Hopkins University. Mailing address: The Johns Hopkins University, School of Hygiene and Public Health, 615 North Wolfe Street, Baltimore, Maryland, USA 21205. Tel: 1-410-955-9854; fax: $1-410-955-7159$ or $1-410-550-6733$
}

vae to complete their preadult development in a great variety of natural and artificial container habitats. While larval infestation of certain containers, such as tires and cans, has been reported throughout aegypti's range, such infestation of other vessels (notably water storage and houseplant containers) has reportedly been very important in some areas and practically nonexistent in others. In the case of water storage containers, as Barrera et al. (1) demonstrated in Venezuela, such variation usually relates to whether or not the local supply of drinking water is reliable. The purpose of the study reported here was to examine possible reasons accounting for infestation variations in houseplant containers.

As larval habitats, houseplant containers tend to be important mainly in urban areas and to show great variations in importance from one neighborhood to another. For example, in Trinidad and Tobago Rosenbaum et al. reported that houseplants were the greatest single source of larval infestation in urban areas, accounting for 
$23 \%$ of the positive containers; while in rural areas they were in sixth place, accounting for only $3 \%$ of the positive containers (2). In addition, the role of these containers tends to vary greatly from one neighborhood to another. For instance, a study of five cities of Puerto Rico by Moore et al. reported that houseplants were an extremely important container habitat in one of the cities, due to an unusually high number of flower pots and plants rooting in water in one of the four sectors of that city (3).

Following a large dengue epidemic in Rio de Janeiro in 1986-1987 and significant numbers of reported dengue cases in almost all regions of Brazil, public health authorities have begun to search for alternatives to vertically organized programs for controlling aegypti, the disease's mosquito vector $(4,5)$. In the past, control program personnel would instruct householders to dispose of their plants or puncture the trays or pots so that water would drain out. However, such an approach no longer appears feasible in a society where people are aware of their rights and reluctant to allow strangers into their homes to carry out control measures (6).

In Marília, Brazil, houseplant containers have consistently been reported as the first or second leading source of $A$. aegypti larval infestation. Such containers accounted for $31 \%$ of the total larvae-positive containers in larval surveys conducted by vector control personnel in 1992. Despite intense dissemination of information about dengue, its mode of transmission, and ways to prevent mosquitoes from breeding in aquatic and potted plant containers, there has been essentially no change in the level of plant container infestations.

The aims of the study reported here were as follows:

(1) To collect specific information about the plant-related containers that serve as larval habitats and the plant species found in them so that control efforts and educational messages can be more focused; and
(2) To evaluate the acceptability of current recommendations for preventing mosquitoes from reproducing in plant and related containers, so that more acceptable recommendations might be developed.

\section{MATERIALS AND METHODS}

\section{Study area}

Marília is a city of 160872 located in Southeastern Brazil's São Paulo State, about $450 \mathrm{~km}$ west of São Paulo (the state capital). The mean temperature is $25{ }^{\circ} \mathrm{C}$, with highs of $35-38^{\circ} \mathrm{C}$ during the summer months (DecemberMarch). The city enjoys a high level of basic services: $98 \%$ of the residents have access to piped water; $97 \%$ are connected to the network of sewers; and $100 \%$ receive regular refuse collection. In the 1980s A. aegypti started to invade the western part of the state, while A. albopictus (Skuse) started to invade the eastern part (5). A. aegypti was documented in Marília for the first time in 1985. In 1992 A. albopictus started entering the western part of the state where Marília is located, but at present A. aegypti is still by far the predominant species. In 1994 Marília's first dengue outbreak was confirmed-there being 15 recorded cases that year and another 33 in 1995. All of these cases occurred between the months of December and June. There is concern that a major dengue epidemic could occur in the area in the near future.

\section{Larval surveys}

Surveys for container-breeding mosquito larvae have been conducted since November 1993 in four study areas of the city and will continue until November 1997. Each area contains about 80 blocks. Inspections are conducted every two months. In the blocks to be surveyed, every second house is inspected. Each November all the blocks are surveyed, while in other months only a sample of blocks in each area is inspected which includes approximately $15 \%$ of the premises.
In the latter case, the blocks to be inspected are chosen systematically, the interval between blocks depending on the number of blocks in the area and the average number of houses per block. The first block for the systematic sample is selected using a random numbers table. Inspectors use a standardized form that requires them to classify each container encountered according to whether it is dry, with water but without larvae, or with larvae; what its use is (water storage, animal drinking dish, plant-related, disposable, or miscellaneous); and the specific type of container it is (e.g., aquatic plant, dish under potted plant, etc.).

\section{Interviews on knowledge and practices}

In 1994 a survey of dengue-related knowledge and practices was administered to a systematic sample of 459 respondents. The survey included questions on knowledge and practices related to dengue, participation in community organizations, and measures taken to control mosquitoes. Only questions specifically relating to plants will be reported in this article.

After the survey, in-depth semistructured interviews $(7,8)$ were conducted with informants selected on the basis of their familiarity with the neighborhood and community-wide problems. To verify local plant terminology, 126 people were asked to make a free listing of the types of plants they had in their homes $(9,10)$. Subsequently an exploratory series of 20 in-depth interviews were conducted with people found to have potted plants positive for $A$. aegypti, in order to investigate knowledge and practices that might favor the presence of mosquito larvae.

\section{RESULTS}

\section{Larval surveys}

From November 1993 to September 1995, 16586 premises were inspected in the four study areas. Of these, 777 or $4.7 \%$ had at least one container posi- 
TABLE 1. Plant-related containers found at the 16586 inspected premises, by type of container; first three columns of figures: the average numbers of containers, containers with water, and containers with aegypti larvae per 100 premises inspected for each type of container; the next three columns: these data as a percentage of all the containers, containers with water, and containers with larvae encountered

\begin{tabular}{|c|c|c|c|c|c|c|}
\hline \multirow[b]{2}{*}{$\begin{array}{l}\text { Type of } \\
\text { container }\end{array}$} & \multicolumn{3}{|c|}{$\begin{array}{c}\text { Average No. of containers per } 100 \text { premises } \\
\text { inspected }\end{array}$} & \multicolumn{3}{|c|}{ Proportion of: } \\
\hline & $\begin{array}{l}\text { All containers } \\
\text { (dry and with } \\
\text { water) }\end{array}$ & $\begin{array}{l}\text { Containers } \\
\text { with water }\end{array}$ & $\begin{array}{l}\text { Containers } \\
\text { positive for } \\
\text { A. aegypti }\end{array}$ & $\begin{array}{l}\text { All containers } \\
\text { (dry and with } \\
\text { water) }\end{array}$ & $\begin{array}{l}\text { Containers with } \\
\text { water }\end{array}$ & $\begin{array}{l}\text { Containers } \\
\text { positive for } \\
\text { A. aegypti }\end{array}$ \\
\hline \multicolumn{7}{|l|}{ Containers for: } \\
\hline Live plants kept in water & 18.05 & 14.06 & 1.07 & $3.8 \%$ & $24.3 \%$ & $48.8 \%$ \\
\hline \multicolumn{7}{|l|}{$\begin{array}{l}\text { Plates, dishes, or cups placed } \\
\text { under plants to catch water: } \\
\text { Plates placed under pots or }\end{array}$} \\
\hline xaxim & 424.10 & 39.00 & 0.83 & $89.3 \%$ & $67.4 \%$ & $37.7 \%$ \\
\hline Drip cups (pingadeiras) & 5.63 & 1.41 & 0.01 & $1.2 \%$ & $2.4 \%$ & $0.4 \%$ \\
\hline \multicolumn{7}{|l|}{$\begin{array}{l}\text { Clay or plastic plant pots } \\
\text { with water accumulated }\end{array}$} \\
\hline
\end{tabular}

tive for A. aegypti. Of the 33194 containers with water that were inspected, 1132 or $3.4 \%$ were positive. The overall Breteau Index was 6.8 positive containers per 100 premises. However, premises indices varied from $0.3 \%$ in the winter months (July-September) to $13.6 \%$ during the summer months (December-March), while Breteau indices reached a high of 18.5 positive containers per 100 premises inspected during the summer months. Immature forms of A. albopictus (Skuse) were encountered in 32 containers during the same period throughout the whole municipality. Six of the 32 were found in plant pots or vases.

Categories of containers most frequently found to be positive for $A$. aegypti were nonuseful, nonreturnable containers $(44.1 \%$ of all positive containers), plant pots and vases (30.9\%), other useful (including returnable) containers $(11.8 \%)$, animal drinking dishes $(7.3 \%)$, and water storage vessels $(5.9 \%)$. Detailed analysis of patterns of positivity in nonuseful nonreturnable containers has been provided elsewhere (11).

There were two situations where larvae were found associated with plants in water-when the plants were being kept permanently in water (without soil) and when the plants were cut flowers in water. The former accounted for $48.8 \%$ of all the aegypti-positive plant-related containers (Table 1). Control programs have recommended that people replace the water with sand or add gelatin to the water to reduce the risk of larval infestation, but we found this recommendation to be rarely if ever implemented. Bunches of cut flowers, usually purchased in a store, were more numerous than plants kept permanently in water; but many were dry, and for this reason they were much less likely to be positive, accounting for only $1.8 \%$ of all the aegypti-positive containers and only $5.0 \%$ of the aegypti-positive plantrelated containers.

Two types of containers located under plants (plates and drip cups) were found positive. Plates were by far the most common, accounting for $89.3 \%$ of all plant-related containers, $37.7 \%$ of all aegypti-positive plantrelated containers, and $11.8 \%$ of the positive containers of all types. Drip cups or pingadeiras are small cups located $5 \mathrm{~cm}$ or more below pots with metal frames that hold them above the ground. These containers accounted for only $0.4 \%$ of all the positive plantrelated containers and only $0.1 \%$ of all positive containers.

A final location for mosquito larvae was in water above the soil of a potted plant, in situations where excessive rain or excessive watering had left too much water in the pot for the soil to absorb. This uncommon situation was first noted by inspectors during January 1995, when it was formally made a category on the larval survey instrument. In this study it was observed exclusively during the height of the rainy season between November and March.

\section{General knowledge about dengue and houseplants}

The survey of 459 respondents indicated that their knowledge of dengue was very good, $78.2 \%$ of the respondents mentioning dengue's correct mode of transmission at least once in the interview. In response to an openended question on breeding sites of the dengue mosquito, $80.4 \%$ of those surveyed mentioned standing water, $16.3 \%$ tires, $15.3 \%$ cans, and $14.8 \%$ plant vases or pots. Only two respondents mentioned trees as breeding 
sites, and only one mentioned the plate under plants growing in xaxim (described below), although this latter habitat has been noted repeatedly in health education on dengue prevention in Marília. Of 343 respondents who said how often they watered their plants, $85(24.8 \%)$ said they watered their plants once a day, 118 (34.4\%) said they did so every other day, and $140(40.8 \%)$ said they did so once a week.

\section{Identification of plant species associated with $A$. aegypti larvae}

Table 1 makes two points very clear. First, potential larval habitats in plantrelated containers are common, the average found being 474.9 per every 100 premises. Second, it is rare to find mosquito larvae in plant containers, because $A$. aegypti larvae were found in only $2.2(0.5 \%)$, on the average, of every 474.9 containers. This positivity rate for plant containers $(0.5 \%)$ was lower than that of water storage containers and animal drinking dishes, both of which had a positivity rate of $0.9 \%$, and slightly higher than that of nonuseful nonreturnable containers $(0.4 \%)$. Because mosquito larvae were only rarely found in plant containers, rather than requesting that people take control measures related to plants in general, it seemed worth asking whether their attention might be directed toward a limited number of specific types of plants most commonly associated with mosquito larvae. To see about this, beginning in January 1995 whenever mosquito larvae were found in plant containers, the type of plant was identified (Table 2).

For 1995, data are available on 45 plant-related containers, excluding cut flower containers, that were found positive for aegypti larvae. Most of these positive containers (33 of 45 or

TABLE 2. Identification of the 45 plants (excluding cut flowers) whose related containers were found positive for A. aegypti larvae in the period January-November 1995

\begin{tabular}{|c|c|c|c|}
\hline \multirow[b]{2}{*}{$\begin{array}{l}\text { Type of plant } \\
\text { (Portuguese names } \\
\text { in parentheses) }\end{array}$} & \multicolumn{3}{|c|}{ A. aegypti larvae found in: } \\
\hline & $\begin{array}{l}\text { Water-bearing } \\
\text { container of plant } \\
\text { kept in water }\end{array}$ & $\begin{array}{l}\text { Plate, dish, or } \\
\text { cup placed under } \\
\text { pot or xaxim }\end{array}$ & $\begin{array}{l}\text { Pot with water } \\
\text { above the soil }\end{array}$ \\
\hline \multicolumn{4}{|l|}{$\begin{array}{l}\text { Nonflowering ornamental plants } \\
\text { (folhagem) }\end{array}$} \\
\hline $\begin{array}{l}\text { Dieffenbachia avoena } \\
\text { (comigo-ninguém-pode) }\end{array}$ & 9 & 1 & 3 \\
\hline $\begin{array}{l}\text { Ferns } \\
\text { Sword fern, Nephrolepis } \\
\text { spp. (samambaia) } \\
\text { Maidenhair fern, Adiantum } \\
\text { spp. (avenca) }\end{array}$ & 0 & 8 & 0 \\
\hline $\begin{array}{l}\text { St. George's sword, } \\
\text { Sansevieria trifasciculata, var. } \\
\text { Laurentii (espada de São Jorge) }\end{array}$ & 2 & 0 & 0 \\
\hline Other nonflowering ornamentals ${ }^{a}$ & 4 & 4 & 1 \\
\hline Flowering ornamentals ${ }^{b}$ & 0 & 3 & 2 \\
\hline Medicinal plants ${ }^{b}$ & 3 & 0 & 0 \\
\hline Edible plants ${ }^{b}$ & 3 & 1 & 0 \\
\hline Totals & 21 & 17 & 7 \\
\hline
\end{tabular}

${ }^{a}$ Four plants identified by species, five identified only as nonflowering ornamental plants (folhagem).

${ }^{b}$ All identified by species name.

$73 \%$ ) held nonflowering ornamental plants (folhagem in Portuguese), two kinds of which (Dieffenbachia avoena, known locally as comigo-ninguém-pode, and ferns) accounted for 22 (49\% of the plant-related infestations). The remaining three plant categories (flowering ornamentals, medicinal plants, and edible plants) together accounted for $12(27 \%)$ of the positive plant containers; no one plant species in any of these three categories accounted for more than two of the infested plant containers.

Dieffenbachia avoena (comigo-ninguémpode) accounted for 13 of the $45(29 \%)$ infested plant containers. The Portuguese term comigo-ninguém-pode literally means "nobody can (do you any harm) in my presence." This refers to a belief that the plant, especially if placed near the door of the house, protects people in the house against bad events such as evil eye (mal olhado), envy, and spirit possession. This plant is either kept permanently in water or planted in soil.

Nonflowering ornamental plants, especially ferns, are commonly grown in xaxim (pronounced "shasheen") instead of in a regular flower pot. Xaxim comes in the form of a block sculpted out of the fibrous trunk of several species of large, tree-like tropical ferns. Although xaxim is porous, it requires no outer pot and maintains humidity well. Ferns, including sword ferns (referred to as samambaia and belonging to the genus Nephrolepis) and a maidenhair fern (referred to as avenca and belonging to the genus Adiantum), accounted for nine of the infested containers. Plants growing in xaxim usually have a plate or dish under them, as there is no pot to catch the water. For eight of the nine positive ferns (all of them sword ferns), aegypti larvae were found in this plate.

\section{Local plant terminology}

A limited number of plant types accounted for most of the infested plantrelated container habitats. One question at this point was: Could these 
TABLE 3. Plants named by over $6(5 \%)$ of 126 respondents asked to list plants they had at home

\begin{tabular}{|c|c|c|c|}
\hline \multicolumn{2}{|c|}{ Names of plants mentioned } & \multicolumn{2}{|c|}{ Respondents } \\
\hline $\begin{array}{l}\text { Portuguese name } \\
\text { (No. positive for } \\
\text { A. aegypti, 1995) }\end{array}$ & $\begin{array}{l}\text { Approximate English translation and/or } \\
\text { Latin name }\end{array}$ & No. & $\%$ \\
\hline Samambaia (8) & Sword fern, Nephrolepis spp. & 71 & $56 \%$ \\
\hline Rosa (0) & Rose & 40 & $32 \%$ \\
\hline $\begin{array}{l}\text { Comigo-ninguém- } \\
\text { pode (13) }\end{array}$ & $\begin{array}{l}\text { Nobody can (hurt you) in my presence, } \\
\text { Dieffenbachia avoena }\end{array}$ & 33 & $26 \%$ \\
\hline Violeta (1) & African violet, Saintpaulia africana & 28 & $22 \%$ \\
\hline Hortelã (0) & Mint & 22 & $17 \%$ \\
\hline Erva cidreira $(0)$ & Balm mint, Melissa officinalis & 22 & $17 \%$ \\
\hline Boldo (0) & Medicinal tea taken for liver ailments & 16 & $13 \%$ \\
\hline Folhagem $(5 \text { or } 9)^{a}$ & Nonflowering leafy ornamental plant & 13 & $10 \%$ \\
\hline Avenca (1) & Maidenhair fern, Adiantum spp. & 13 & $10 \%$ \\
\hline Alface $(0)$ & Lettuce & 10 & $8 \%$ \\
\hline Erva doce $(0)$ & Anise, Pimpinella anisum & 10 & $8 \%$ \\
\hline Margarida $(0)$ & Daisy & 9 & $7 \%$ \\
\hline Espada de São Jorge (2) & St. George's sword, Sansevieria trifasciata & 9 & $7 \%$ \\
\hline Flor de Maio (1) & Mayflower, Schlumbergera hybrid & 8 & $6 \%$ \\
\hline Couve $(0)$ & Cabbage, kale & 8 & $6 \%$ \\
\hline Puejo (1) & Medicinal tea taken for kidney ailments & 7 & $6 \%$ \\
\hline Anturio (0) & Anthurium andreanum & 7 & $6 \%$ \\
\hline
\end{tabular}

${ }^{a}$ Depends on whether broad or narrow definition is used (see text).

plants be referred to by their specific names in educational materials? Therefore, the next step in developing an intervention for plant containers was to ask 126 plant owners to list all the plants they had in their homes. A total of 105 different plant names were elicited, of which 17 names (16\%) were mentioned by more than $5 \%$ of the respondents (Table 3). Of these 17 most frequently mentioned names, eight were identified as having been associated with $A$. aegypti larvae in the larval surveys, four of them twice or more. There were therefore four names that seemed generally recognized and that had been associated with aegypti larvae more than once. These were samambaia (referring to sword ferns, Nephrolepis spp.), comigo-ninguém-pode (referring to Dieffenbachia avoena), folhagem (literally "foliage," referring to various nonflowering leafy ornamental plants), and espada de São Jorge (referring to St. George's sword, Sanse- vieria trifasciculata, Laurentii). The best interpretation of the term folhagem (foliage) is uncertain. Among residents of the study area it usually refers to a nonflowering ornamental plant for which they have no other name, or in general to all such plants except ferns, Dieffenbachia avoena, and St. George's sword. In its broadest possible application, the term folhagem refers to 33 of the 45 plants with aegypti-infested containers. Excluding the other three names, it refers to nine of the 33 plants (see Table 2). However, larval survey inspectors obtained other specific names for four of these nine, leaving only five infested plants with the "miscellaneous" designator of folhagem.

\section{Interviews with people having infested plant containers}

Interviews were conducted with 20 people selected because each had the following items: a plant-related container positive for $A$. aegypti and a sword fern (samambaia) or a Dieffenbachia avoena (comigo-ninguém-pode) plant. Despite the fact that all 20 people had one of these plants in water, only four admitted to it. This was probably out of concern that they would be told by the control program to eliminate the plant. Of the four who admitted to maintaining plants in water, three said they changed the water to protect it from mosquitoes.

Questioned generally about their plants, most (16 of the 20 subjects) said that they had no problems with their plants, while the rest expressed concern with yellow or wilted leaves.

All 20 admitted to owning a comigoninguém-pode plant. Eight said they had bought the plant, while 12 reported being given it by someone. The control program in São Paulo State encourages people to either replace the water with sand or put gelatin in the water to protect it from larvae. Only two had heard that either method might be appropriate for a comigoninguém-pode plant in water. Nine people said they had the plant for decoration; only four said they had it because of a belief it would protect them against "evil eye" or other forms of bad luck. A typical exchange (from interview \#IC20802AM) went as follows:

Interviewer: "Some people believe that some plants can protect the house, against envy for example. Do you know anything about this?"

Respondent: "I don't believe in this. Now I have comigo-ninguém-pode, but you need to have the husband (the male plant) and a sword of St. George too. They protect the house, save it from evil eye. Now, if you don't look after the plant it won't on its own protect you. I think it's a bit of a folk-tale."

Interviewer: "Do you believe in it?"

Respondent: "I'm straddling the fence, I don't believe and I don't disbelieve. It doesn't get you anywhere abusing this world, there's so much going on..."

Sixteen of the 20 respondents also said that they owned a fern; and in 15 of the 16 cases the plant had been purchased. Eleven of the 16 reported that 
they watered the fern at least twice a week; eight of the 16 said they both eliminated excess water in the plate under the xaxim and washed the plate at least once a week. Nine had heard of the recommended way of protecting the plate from larvae by filling the plate with sand, but none were applying the method. Explanations for this included not being in the habit of doing it (3/9), disliking the idea (2/9), and not having sand (1/9). In responding to open-ended questions, most of the 20 people interviewed expressed the opinion that the recommended control methods (such as replacing water with sand for aquatic plants) were both displeasing to the eye and bad for the plant.

\section{DISCUSSION AND CONCLUSIONS}

Since the beginning of dengue prevention efforts in Marília in 1989, it has been recognized that houseplantrelated containers are important $A$. aegypti larval habitats. For this reason, plant-related containers have been emphasized in educational materials. Despite this, there has been little or no change in the levels of larval infestation attributable to plants.

On the basis of the results obtained in this study, we suggest that the control measures have not been accepted or embraced for the following reasons:

(1) While there is a huge number of houseplants, only a very low percentage of them harbor mosquito larvae, making it difficult for people to recognize their importance as a source of mosquitoes. If people do happen to see larvae, they do not recognize them as belonging to a stage in the mosquito's life cycle.

(2) Control program personnel have taken an aggressive attitude to- ward houseplants, entering houses to place sand in vases and plates or insecticide in plant water. This has made people think that the control program is against people having plants. There is much anecdotal evidence of this, such as observations of people placing their aquatic plants in refrigerators, closets, or bedrooms when control program personnel come to inspect the house. Many people reported an emotional attachment to their plants, conversing with them, caring for them, and believing in their power to protect the household from various forms of bad luck. The dengue control program, viewed as the enemy of plants, has low credibility as a source of information about how to care for plants, resulting in low acceptance of recommended measures.

(3) Many of the recommendations made regarding ways to prevent mosquitoes from breeding in houseplants have been so general that they have led to confusion. People have been told to take action to keep mosquitoes out of "plants," a term that includes not only potted plants but also lettuce, trees, and other plants not commonly associated with mosquito larvae. In addition, the suggested alternatives for control (such as placing sand in plates under houseplants) are seen as bad for the plant and aesthetically displeasing.

In essence, control programs have adopted the same aggressive approach toward control of houseplants as they have toward control of nonuseful nonreturnable containers such as tin cans and plastic cups; and they have failed to recognize that the well-being of houseplants is at least as important as dengue prevention to many people. In fact, therefore, the acceptability of control measures is related largely to their impact upon plants; and control program personnel are viewed as not very concerned about plants.

All three of these issues are addressed in an intervention currently being developed. First, instead of discussing the innumerable types of plants in general, emphasis is being placed on two specific types of plants identified in larval surveys and freelistings as being publicly recognized and also as being strongly associated with aegypti larvae. These two types of plants are ferns and Dieffenbachia avoena (comigo-ninguém-pode). Second, instead of using the control program as the source of information, other sources (such as botanists) with greater credibility for plant-lovers are being used. Finally, alternative plant care recommendations are being developed that will be seen as beneficial to the plants involved and will hopefully enjoy greater public acceptance.

Acknowledgments. We are grateful to the many members of the Regional Office of the Superintendência de Controle de Endemias (SUCEN) in Marília who participated in the field research. In addition, the collaboration and support of the Municipal Secretary of Hygiene and Health, Dr. Adib Haber, and the General Coordinator of the Municipal Secretariat of Hygiene and Health, Dr. Cássio Luiz Pinto, have been invaluable to us.

Research described in this paper was funded by SUCEN, State Secretariat of Health, São Paulo State. Dr. Francisco Pinheiro of PAHO arranged support for Cássia Mazine and Sueli Yasumaro to receive training on research methods in community-based dengue control at Johns Hopkins University. The PAHO office in Brasília provided funding for Dr. Peter Winch to travel to Brazil as a consultant to the project. 


\section{REFERENCES}

1. Barrera R, Ávila J, González-Téllez S. Unreliable supply of potable water and elevated Aedes aegypti larval indices: a causal relationship? J Am Mosq Control Assoc 1993;9(2): 189-195.

2. Rosenbaum J, Nathan MB, Ragoonanansingh R, Rawlins S, Gayle C, Chadee DD, et al. Community participation in dengue prevention and control: a survey of knowledge, attitudes and practice in Trinidad and Tobago. Am J Trop Med Hyg 1995;53(2): 111-117.

3. Moore CG, Cline BL, Ruiz-Tibén E, Lee D, Romney-Joseph H, Rivera-Correa E. Aedes aegypti in Puerto Rico: environmental determinants of larval abundance and relation to dengue virus transmission. Am J Trop Med Hyg 1978;27(6):1225-1231.
4. Marzochi KBF. Dengue in Brazil: situation, transmission and control, a proposal for ecological control. Mem Inst Oswaldo Cruz 1994; 89(2):235-245.

5. Pontes RJS, Ruffino Netto A. Dengue in an urban locality of Southeastern Brazil: epidemiological aspects. Rev Saúde Pública (São Paulo) 1994;28(3):218-227.

6. Winch PJ, Lloyd LS, Hoemeke L, Leontsini E. Vector control at the household level: an analysis of its impact on women. Acta Trop 1994;56:327-339.

7. Bernard HR. Research methods in anthropology. Thousand Oaks (California): Sage Publications; 1992.

8. Spradley JP. The ethnographic interview. New York: Harcourt Brace Jovanovich; 1979.
9. Weller SC, Romney AK. Systematic data collection. Thousand Oaks (California): Sage Publications; 1988 .

10. Borgatti S. ANTHROPAC 3.2. Columbia (South Carolina): Analytic Technologies; 1990.

11. Mazine $C A B$, Macoris MLG, Yasumaro $S$, Andrighetti MTM, Silva ME, Nelson MJ, et al. Disposable containers as larval habitats for Aedes aegypti in a city with regular refuse collection: a study in Marília, São Paulo State, Brazil. Acta Trop 1996;62:1-13.

Manuscript received 15 March 1996. Revised version accepted for publication on 10 December 1996.

RESUMEN Desde 1985, después de la reinfestación de mosquitos Aedes aegypti (L.) en el Estado de São Paulo, se encontró que - a pesar de la diseminación de mensajes educativos destinados a su control- las macetas y floreros son un hábitat importante de las larvas.

Factores que favorecen la infestación de recipientes con plantas domésticas por larvas de Aedes aegypti en Marília, São Paulo, Brasil
Los objetivos de este estudio fueron identificar las macetas y floreros como hábitats de larvas de mosquitos en relación con su número y grado de infestación, los tipos de plantas involucradas y la localización específica de las larvas; investigar los nombres locales de las plantas domésticas y examinar los factores que afectan al cumplimiento de las medidas de control. Los resultados mostraron un promedio de más de cuatro posibles hábitats de larvas relacionados con plantas por cada sitio, de los cuales solo 0,4\% tenían el vector. Los recipientes para plantas representaron 31\% de todos los receptáculos con larvas de $A$. aegypti. A pesar de que de una muestra de 126 personas entrevistadas enumeraron 105 nombres de plantas domésticas, 49\% de las plantas asociadas con larvas fueron solo de dos tipos: helechos y la planta ornamental Dieffenbachia avoena. La evidente falta de voluntad de la población para aceptar las medidas de control contra $A$. aegypti en lo que respecta a plantas domésticas parece deberse a la poca frecuencia relativa de $A$. aegypti en los recipientes domésticos, la falta de confianza en los programas de control como fuente idónea de información sobre plantas y la opinión de que las medidas de control recomendadas son dañinas para las plantas. Actualmente se está planeando una intervención para el control del dengue en la que se usará material educativo que trata específicamente sobre las plantas cuyos recipientes albergan con mayor frecuencia las larvas de $A$. aegypti. También se hará uso de fuentes de información botánica con mayor credibilidad en materia de plantas. Además, se formulará un plan diferente con un enfoque más atractivo desde el punto de vista de la salud de las plantas para incrementar su posibilidad de aceptación. 